Article

\title{
Development of a Solid Bioherbicide Formulation by Spray Drying Technology
}

\author{
Thiago C. de Almeida ${ }^{1}$, Stefani S. Spannemberg ${ }^{1}$, Thiarles Brun ${ }^{1}$, Silvana Schmaltz ${ }^{1}{ }^{1}$,

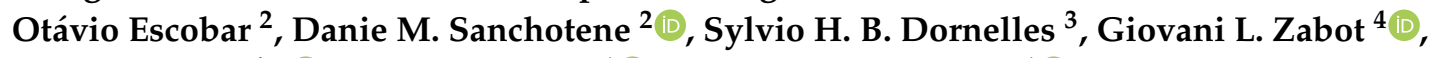 \\ Marcus V. Tres ${ }^{4 *} * \mathbb{D}$, Raquel C. Kuhn ${ }^{1}$ (D) and Marcio A. Mazutti ${ }^{1}$ (D) \\ 1 Department of Chemical Engineering, Federal University of Santa Maria, Av. Roraima, 1000, \\ Santa Maria RS 97105-900, Brazil; eng.thiagocastro@yahoo.com.br (T.C.d.A.); \\ stefani.segato@gmail.com (S.S.S.); brun.thiarles@gmail.com (T.B.); silschmaltz@gmail.com (S.S.); \\ raquelckuhn@yahoo.com.br (R.C.K.); mazutti@ufsm.br (M.A.M.) \\ 2 Biomonte SA, St. Appel, 472, room 401, Santa Maria RS 97015-030, Brazil; otescobar@gmail.com (O.E.); \\ danie.sanchotene@biomonte.com.br (D.M.S.) \\ 3 Department of Biology, Federal University of Santa Maria, Av. Roraima, 1000, Santa Maria RS 97105-900, \\ Brazil; sylviobidel@gmail.com \\ 4 Laboratory of Agroindustrial Processes Engineering (LAPE), Federal University of Santa Maria, 1040, \\ Sete de Setembro St., Center DC, Cachoeira do Sul RS 96508-010, Brazil; giovani.zabot@gmail.com \\ * Correspondence: marcus.tres@ufsm.br; Tel.: +55-51-3724-8417
}

Received: 30 April 2020; Accepted: 5 June 2020; Published: 9 June 2020

\begin{abstract}
This study aimed to compare the herbicidal activity of solid formulas obtained by spray drying with conventional liquid formulas containing biomolecules produced by submerged cultivation of the fungus Diaporthe sp. in a stirred-tank bioreactor. The solid formula presented the highest phytotoxicity on plant control $(96.7 \%)$ and the phytotoxicity was directly related to the concentration of fermented broth in the formula. The use of adjuvant improved the efficiency of the bioherbicide. Dry matters of treatments were lower than the control and this was correlated with an increase in oxidative stress, since the activity of the antioxidant enzymes such as superoxide dismutase and guaiacol peroxidase increased in the treatment with a high level of phytotoxicity. Spray drying technology is a promising tool to concentrate bioherbicide without the loss of bioactive compounds since one of the major challenges in the production of bioherbicides is the low concentration of active ingredients in the fermented broth.
\end{abstract}

Keywords: Diaporthe sp.; antioxidant enzymes; natural herbicide; bioproducts

\section{Introduction}

Microorganisms produce several biomolecules with different structural and biological characteristics. In certain cases, they can cause pathogenicity in host plants, destroying their structure and causing necrotic or chlorotic lesions. These biomolecules are secondary metabolites that can be a promising source for the production of new natural herbicides or the discovery of new molecules [1-3]. The scarcity of new molecules in the last decades and the increase in cases of weed resistance to current herbicides show the importance of seeking new tools for weed management. Currently, there are 498 herbicide-resistant biotypes included in 235 species present in 82 cultures and 65 countries [4].

Current studies are focused on plant pathogenic microorganisms such as fungi and bacteria for producing a variety of potential and often specific phytotoxins for certain plants that are capable of causing lesions, inhibiting growth, and in some cases, leading to the death of target plants $[3,5,6]$. The genus Diaporthe sp. (teleomorph of the genus Phomopsis) has been studied and described by several researchers as a genus of a fungus with high biotechnological potential [7]. It has already been 
described as a producer of secondary enzymes and metabolites [8] with antibiotic [9], fungicide [10], and anticancer [11] potentials as well as in the biological control of weeds [12-15].

Major challenges in the production of biomolecules are to maintain their stability in aqueous solution, once a variety of drawbacks occur such as the possibility of contamination by microorganisms and chemical and physical degradations during the transport, storage, and application steps. In this sense, dehydrated formulations have advantages over aqueous enzymatic extracts, providing increased shelf life and practical handling [16,17]. The selected drying technique is very important and should be able to preserve the biomolecules during the process. Among the drying techniques most widely used for biomolecules (enzymes, proteins, and metabolites in general) are convective drying, freeze-drying, spray drying, and fluidized bed $[18,19]$.

Formulations of dehydrated biomolecules with a spray drying technique provide some benefits, such as increased shelf life and ease of use [17]. This spray drying technique has been widely used for many industrial enzymes such as $\alpha$-amylase from Aspergillus oryzae, recombinant alkaline protease from Bacillus subtilis, and Bacillus licheniformis alkaline protease [20]. Jesus et al. [21] evaluated the efficiency of the drying processes by spray drying and freeze-drying to formulate the $\alpha$-amylase enzyme produced from Bacillus sp. The authors observed high viability of using the spray drying technique. However, the use of spray drying technology to obtain a solid formulation containing biomolecules as active ingredients for use as an herbicide is a novel recent strategy reported in the scientific literature. A viable solid formulation for use as a bioherbicide containing active biomolecules obtained by Diaporthe sp. could be a promising option for weed control.

Based on these aspects, the main objective of this work was to evaluate a technical strategy to obtain solid formulas containing active biomolecules produced by Diaporthe sp. by using spray drying technology. The bioherbicide potential of the solid formulas was also compared with the liquid formulas obtained directly through submerged fermentation. The formulas were applied on a lettuce (Lactuca sativa) test plant. The phytotoxicity, dry matter, and the activities of the antioxidant enzymes such as superoxide dismutase enzyme activity (SOD) and guaiacol peroxidase enzyme activity (POD) were assessed.

\section{Materials and Methods}

\subsection{Microorganism, Inoculum, and Fermentation}

The strain used in this study was Diaporthe sp., previously isolated by Souza et al. [15]. The culture was maintained in potato dextrose agar (PDA) at $4^{\circ} \mathrm{C}$ and subcultured every 15 days. Cell production for pre-inoculum was prepared by incubating the microorganism in a Petri dish containing PDA for 8 days at $28^{\circ} \mathrm{C}$. For the inoculum, two fungal mycelia discs of $6 \mathrm{~mm}$ were transferred to a $250 \mathrm{~mL}$ Erlenmeyer flask containing $100 \mathrm{~mL}$ of a medium composed by $\left(\mathrm{g} \mathrm{L}^{-1}\right)$ : glucose (10.0), peptone (7.5), yeast extract (2.0), $\left(\mathrm{NH}_{4}\right)_{2} \mathrm{SO}_{4}(1.0), \mathrm{FeSO}_{4} \cdot 7 \mathrm{H}_{2} \mathrm{O}(1.0), \mathrm{MnSO}_{4} \cdot \mathrm{H}_{2} \mathrm{O}(1.0)$, and $\mathrm{MgSO}_{4}$ (0.5). The flasks were maintained at $28^{\circ} \mathrm{C}$ and $120 \mathrm{rpm}$ for seven days (Innova 44R, New Brunswick, Canada) [15].

The fermentations were carried out in a stirred-tank bioreactor (BIOTEC-C, Tecnal, Piracicaba, Brazil) in batch mode, containing $3 \mathrm{~L}$ of the culture medium. The fermentations were started using $10 \%(v / v)$ of inoculum at an initial $\mathrm{pH}$ of 6.0 and $28^{\circ} \mathrm{C}$ for seven days. The fermentation medium was composed of corn steep liquor $(10 \% v / v)$, sucrose $\left(20 \mathrm{~g} \mathrm{~L}^{-1}\right),\left(\mathrm{NH}_{4}\right)_{2} \mathrm{SO}_{4}\left(2 \mathrm{~g} \mathrm{~L}^{-1}\right), \mathrm{MgSO}_{4} \cdot 7 \mathrm{H}_{2} \mathrm{O}$ $\left(0.5 \mathrm{~g} \mathrm{~L}^{-1}\right), \mathrm{FeSO}_{4} \cdot 7 \mathrm{H}_{2} \mathrm{O}\left(1 \mathrm{~g} \mathrm{~L}^{-1}\right)$, and $\mathrm{MnSO}_{4} \cdot \mathrm{H}_{2} \mathrm{O}\left(1 \mathrm{~g} \mathrm{~L}^{-1}\right)$. Biomass was separated from the fermentation broth by filtration using filter paper (Whatman; number 2), followed by centrifugation (Eppendorf, model 5804R, Hamburg, Germany) at 10,000 rpm for $10 \mathrm{~min}$ and the supernatant (bioherbicide containing active biomolecules) was used in the formulations. 


\subsection{Development of Formulations}

\subsubsection{Liquid Bioherbicide Formulations}

Different solutions containing water, bioherbicide $(5 \%, 25 \%$, and $100 \%, v / v)$, and adjuvant $(0 \%$ and $1 \%, v / v$ ) were prepared. The final volume of the solutions was always $1000 \mathrm{~mL}$. The adjuvant used was the commercial product AgRho ${ }^{\circledR}$ FKC 1500 (Rhodia, Sao Paulo, Brazil). The products and concentrations were selected based on preliminary experiments (data not shown). The components of each formula were homogenized using a mechanical stirrer operating at $300 \mathrm{rpm}$ for $15 \mathrm{~min}$. After homogenization, the liquid solution was used directly in the bioassays.

\subsubsection{Solid Bioherbicide Formulations}

The solid bioherbicide formulation was obtained using a lab-scale spray dryer (LabMaq, model LM MSDi 1.0, Ribeirão Preto, Brazil) composed of a stainless-steel spray assembly with two fluid nozzles where the inner nozzle develops the liquid jet and the outer nozzle develops the compressed air outlet. The compressed air atomizes the liquid as it emerges from the jet to form the required spray. The operational parameters of feed and air flowrates were optimized as described below. The pressure of atomization was maintained at $0.3 \mathrm{MPa}$ and the outlet air temperature was $125^{\circ} \mathrm{C}$.

Initially, a central composite rotatable design (CCRD) for two independent variables was fulfilled in order to optimize the feed and air flowrates with the aim of maximizing the solid yield after drying the solids. The range of investigated variables is presented in Table 1 . In these experiments, only water was used instead of metabolites from fermentation. At the end of the process, the mass of dried solids was determined and the yield was calculated, based on the initial solid mass (100 g). At the optimized condition, the solid formulation of bioherbicides was prepared after drying the fermentation broth.

Table 1. Solid yield after performing spray drying following the experimental runs of the Central Composite Rotatable Design (CCRD).

\begin{tabular}{cccc}
\hline Runs & Feed Flowrate $\left(\mathbf{L ~ h} \mathbf{~}^{-\mathbf{1}}\right)$ & Air Flow Rate $\left(\mathbf{L} \mathbf{~ m i n}^{-\mathbf{1}}\right)$ & Solid Yield $\mathbf{( w t} \mathbf{o})$ \\
\hline 1 & $0.5(-1)$ & $1.4(-1)$ & 16.61 \\
2 & $1.7(1)$ & $1.4(-1)$ & 9.22 \\
3 & $0.5(-1)$ & $3.6(1)$ & 11.70 \\
4 & $1.7(1)$ & $3.6(1)$ & 11.39 \\
5 & $0.2(-1.41)$ & $2.5(0)$ & 19.23 \\
6 & $2.0(1.41)$ & $2.5(0)$ & 10.46 \\
7 & $1.1(0)$ & $1.0(-1.41)$ & 10.23 \\
8 & $1.1(0)$ & $4.0(1.41)$ & 9.33 \\
9 & $1.1(0)$ & $2.5(0)$ & 13.59 \\
10 & $1.1(0)$ & $2.5(0)$ & 11.02 \\
11 & $1.1(0)$ & $2.5(0)$ & 12.28 \\
\hline
\end{tabular}

To obtain the solid formulas, different solutions $(1000 \mathrm{~mL})$ containing water, bioherbicide $(5 \%$, $25 \%$, and $100 \%, v / v)$, adjuvant $(0 \%$ and $1 \%, v / v)$, and silicon as the inert ingredient were prepared. The final solid mass of solutions was always maintained in $100 \mathrm{~g}$. The dry mass of fermentative broth (bioherbicide) was $12.5 \mathrm{~g} \mathrm{~L}^{-1}$. The mass of silicon was adjusted (75.6-99.4 $\mathrm{g}$ ) to result in a final solid mass of $100 \mathrm{~g}$.

\subsection{Bioassays}

The efficiency of the formulations was evaluated in post-emergence bioassays with lettuce (Lactuca sativa) as test plants. The cultivar Larissa (Sakata seeds) was used, and the plants were acquired through local commerce. They were transplanted into polyethylene cups containing $250 \mathrm{~g}$ of a commercial substrate (Mecplant ${ }^{\circledR}$, Telêmaco Borba, Brazil) without any treatment. Plants were cultivated in a 
greenhouse for 15 days before the application of bioherbicide when the plants reached the two to three-leaf stage. Each treatment comprised three plants in triplicate, with a total of nine plants.

To evaluate the influence of the type of formulation (solid or liquid), the amount of adjuvant $(0 \%$ and $1 \%, v / v)$ and percentage of fermented broth $(5 \%, 25 \%$, and $100 \%, v / v)$ on the efficiency of the bioherbicide, a $2 \times 2 \times 3$ trifactorial experiment was performed. It consisted of 12 runs, which comprised the combination of two types of formulation, the presence or absence of adjuvant, and three percentages of fermented broth. A control test without application was also accomplished. The solid product was dissolved in distilled water before application in a ratio of $100 \mathrm{~g}$ per $1000 \mathrm{~mL}$. The products were applied in post-emergence bioassays using a $\mathrm{CO}_{2}$ pressurized backpack sprayer equipped with a six-point bar DG 11002 flat jet plane, $0.50 \mathrm{~m}$ spacing, $0.28 \mathrm{MPa}$ constant pressure, and a specific volume equivalent to $150 \mathrm{~L} \mathrm{ha}^{-1}$.

In seven days after application (DAA), the scale of Frans and Crowley [22], which is shown in Table 2, was used to evaluate the phytotoxicity. Furthermore, the dry matter (DM) of the aerial part of plants was determined. Superoxide dismutase enzyme activity (SOD) was determined according to the spectrophotometric method described by Giannopolitis and Ries [23] and guaiacol peroxidase enzyme activity (POD) enzyme was determined according to Zeraik et al. [24].

Table 2. Scale for the evaluation of the phytotoxicity in plants according to Frans and Crowley [22].

\begin{tabular}{cccc}
\hline Rates & Attributes & Description Phytotoxicity of the Culture & Rates \\
\hline 0 & No Effects & No injury or reduction & 0 \\
10 & Slight Effect & Slight discoloration or atrophy & 10 \\
20 & & Some discoloration or atrophy & 20 \\
30 & & Injury more pronounced, but not lasting & 30 \\
40 & Moderate Effect & Moderate injury, usually with recovery & 40 \\
50 & & More lasting injury, doubtful recovery & 50 \\
60 & Lasting injury without recovery & 60 \\
70 & Severe Effect & Heavy injury, stand reduction & 70 \\
80 & & Next crop destruction & 80 \\
90 & & Rarely some plants remain & 90 \\
100 & Total Effect & Complete destruction of culture & 100 \\
\hline
\end{tabular}

\subsection{Statistical Analysis}

The analysis of variance (ANOVA) and Scott-Knott test for clustering of the means were performed using the statistical program Sisvar ${ }^{\circledR} 5.3$ [25], considering a significance level of $95 \%(p<0.05)$.

\section{Results and Discussion}

\subsection{Optimization of Operational Variables of Spray Drying Process}

Table 1 presents the results of the CCRD in terms of solid yield after the spray drying process. The highest solid yield was obtained in run $7(19.23 \mathrm{wt} \%)$ with an air flow rate of $2.5 \mathrm{~L} \mathrm{~min}^{-1}$ and a feed flow rate of $0.2 \mathrm{~L} \mathrm{~h}^{-1}$. To better observe the influence of the process variables on solid yield, the data in Table 1 were used to generate a quadratic model (Equation (1)), which presented a high determination coefficient $\left(R^{2}=0.9342\right)$ and was validated by analysis of variance (ANOVA) (the $F$ calculated was 2.8 times higher than the critical $\mathrm{F}$ value at $p<0.05$ ).

$$
\mathrm{SY}=12.30-2.52 \times \mathrm{FF}+1.26 \times(\mathrm{FF})^{2}-0.50 \times \mathrm{AF}-1.29 \times(\mathrm{AF})^{2}+1.77 \times \mathrm{AF} \times \mathrm{FF}
$$

where

SY is the solid yield (wt\%), and FF and FA are the coded values for the feed and air flowrates.

The validated model was used to depict the contour plot presented in Figure 1. The increase of feed flow rate presented a more pronounced negative effect on the solid yield than the increase of air 
flow rate. This can be verified by analyzing the linear coefficients of Equation (1) for both variables. For feed flow rate, the coefficient was -2.52 , whereas for air flow rate, it was -0.50 . Maximum solid yield was obtained for low values of feed and air flow rates. At a high feed flow rate, the residence time was not sufficient to obtain a satisfactory drying of solids. On the other hand, at high air flow rates, the drag of solid particles could have occurred, thus decreasing the yield. Based on these results, the optimum operational condition to obtain a solid formula of bioherbicide was defined as a feed flow rate of $0.2 \mathrm{~L} \mathrm{~h}^{-1}$ and air flow rate of $1.4 \mathrm{Lmin}^{-1}$. As seen in Figure 1, in this region, the maximum solid yield was approximately $20 \mathrm{wt} \%$.

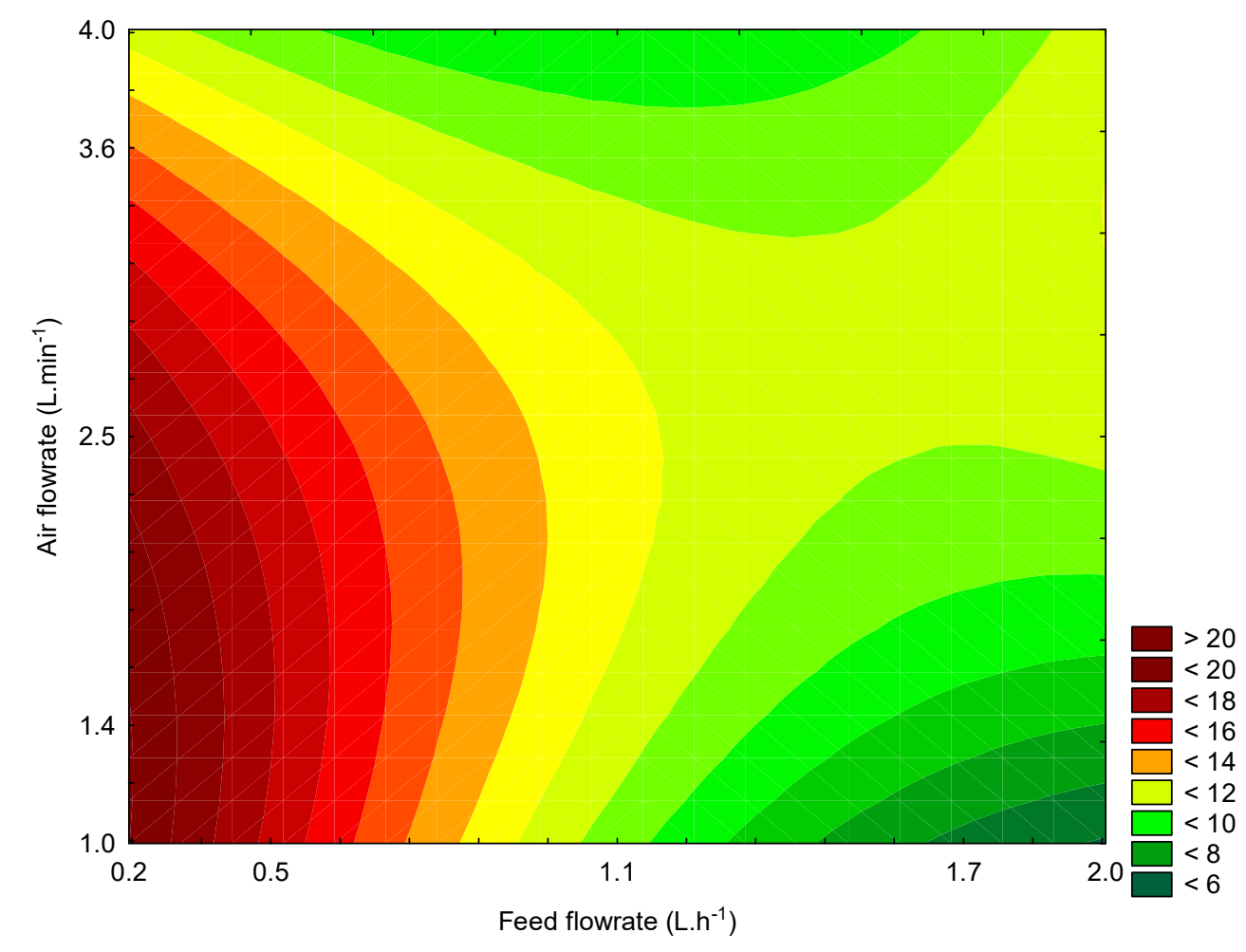

Figure 1. Influence of feed and air flowrates on the solid yield (\%) after the spray drying process.

\subsection{Comparison of Solid and Liquid Formulas of Bioherbicide}

Table 3 shows the results of dry mass and phytotoxicity obtained in the treatments developed in the $2 \times 2 \times 3$ trifactorial experiment, with a statistical difference among them $(p<0.05)$. All variables were statistically significant and presented differences for the responses evaluated. Maximum phytotoxicities for the liquid and solid formulations were $40 \%$ and $96.7 \%$, respectively, both using $100 \%$ of fermentation broth in the mixture. When comparing the different concentrations of fermented broth in the formulas, the phytotoxicity on the lettuce leaves increased with increasing concentration. The findings demonstrate that the fungus Diaporthe sp can produce biomolecules with toxins that act as a herbicide, with the possibility of controlling some plants. Within similar purposes, Bastos et al. [13], using the Cucumis sativus as a test plant, obtained more than $80 \%$ of control using a liquid formulation containing fermented broth of Diaphorte sp. Pes et al. [14] carried out the application of the fermented broth of Diaporthe sp. as a post-emergence bioherbicide against two weeds (Echinochloa sp., Conyza sp.) and observed growth suppression results in both species.

Overall, the solid formulation obtained by the spray drying process presented the best results in terms of bioherbicidal activity since the phytotoxicity against lettuce was higher than the one presented by the liquid formulation, thus confirming the initial hypothesis. The main reason for the best results of the solid formulation is related to the concentration of bioactive compounds in the bioherbicide. Water is removed from the fermented broth by a rapid process, avoiding that the fungal metabolites 
have remarkable losses of biological activity. In this sense, the qualitative (Figure 2) findings and the quantitative (Tables 3 and 4) data demonstrated that the spray drying formulation was able to concentrate the biomolecules with a low level of degradation in the drying process. Otherwise, in the liquid formulation, there is low phytotoxin concentration, since the metabolites produced in the fermentation are diluted in large aqueous volume [26]. In a previous study [27], different processes such as membranes, lyophilization, and evaporation, were assessed for the concentration of a bioherbicide produced from Fusarium fujikuroi. Regarding evaporation, the herbicidal activity was reduced with an increase in temperature, which was expected. The reduction of activity was attributed to the thermal degradation of bioactive molecules, most likely exopolysaccharides. Some other studies have proposed dry formulation with spray drying using organic products, which presented relevant outcomes. The high temperatures in the process practically do not affect the efficiency of the compound since the drying process is fast $[28,29]$. The results were comparable to chemical pesticides in terms of control efficiency, but with the advantage of being an environmentally-friendly pesticide formulation, thus corroborating the inferences done regarding spray drying studied in this work.

Table 3. Evaluation of dry matter (g) and phytotoxicity (\%) as a function of formulation type, use of an adjuvant, and fermented broth concentration.

\begin{tabular}{|c|c|c|c|c|}
\hline Formulation & Adjuvant & Fermentation Broth $(v / v, \%)$ & Dry Matter (g) & Phytotoxicity (\%) \\
\hline \multirow{6}{*}{ Liquid } & \multirow{3}{*}{ Without } & 5 & $0.161 \mathrm{a}$ & $0.0 \mathrm{c}$ \\
\hline & & 25 & $0.144 b$ & $1.7 \mathrm{c}$ \\
\hline & & 100 & $0.126 c$ & $6.7 \mathrm{c}$ \\
\hline & \multirow{3}{*}{ With } & 5 & $0.135 c$ & $5.0 \mathrm{c}$ \\
\hline & & 25 & $0.126 c$ & $13.3 c$ \\
\hline & & 100 & $0.112 \mathrm{c}$ & $40.0 \mathrm{~b}$ \\
\hline \multirow{6}{*}{ Solid } & \multirow{3}{*}{ Without } & 5 & $0.144 b$ & $3.3 \mathrm{c}$ \\
\hline & & 25 & $0.125 c$ & $20.0 \mathrm{~b}$ \\
\hline & & 100 & $0.119 \mathrm{c}$ & $40.0 \mathrm{~b}$ \\
\hline & \multirow{3}{*}{ With } & 5 & $0.138 \mathrm{c}$ & $11.7 \mathrm{c}$ \\
\hline & & 25 & $0.123 c$ & $25.0 \mathrm{~b}$ \\
\hline & & 100 & $0.101 \mathrm{c}$ & $96.7 \mathrm{a}$ \\
\hline \multicolumn{3}{|c|}{ Control } & $0.167 \mathrm{a}$ & $0.0 \mathrm{c}$ \\
\hline
\end{tabular}

* Means followed by the same lowercase letter in the same column do not differ statistically from each other at the level of $5 \%$ of error probability by the Scott-Knott test.

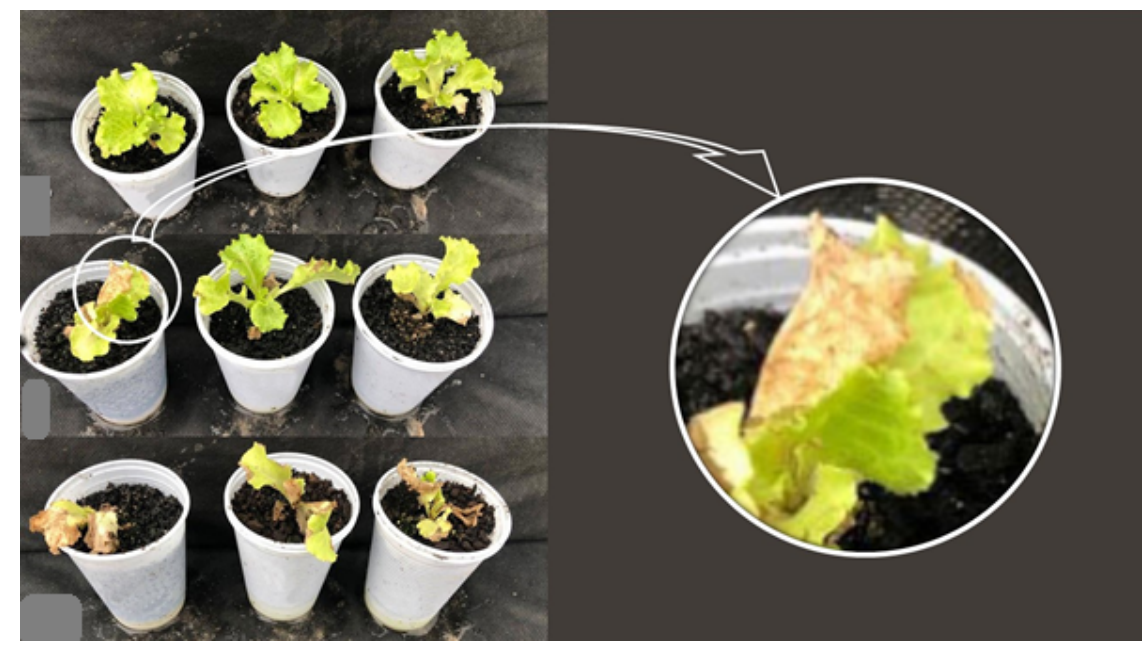

Figure 2. (Left) Triple comparison between control treatment (first row), solid containing 100\% (v/v) of bioherbicide without adjuvant (second row) and solid containing $100 \%(v / v)$ of bioherbicide with adjuvant (third row) at 7 days after application (DAA). (Right) Zoom of necrosis injury caused by the natural herbicide. 
Table 4. Evaluation of antioxidants enzymes Superoxide dismutase (SOD) and Guaiacol peroxidase (POD) as a function of formulation type, use of an adjuvant, and fermented broth concentration.

\begin{tabular}{|c|c|c|c|c|}
\hline Formulation & Adjuvant & $\begin{array}{l}\text { Fermentation } \\
\text { Broth }(v / v, \%)\end{array}$ & $\begin{array}{c}\text { POD (U mg-1 } \\
\text { Protein) }\end{array}$ & $\begin{array}{c}\text { SOD (U mg } \mathbf{~}^{-1} \\
\text { Protein) }\end{array}$ \\
\hline \multirow{6}{*}{ Liquid } & \multirow{3}{*}{ Without } & 5 & $7.5 \mathrm{~b}$ & $224.9 \mathrm{~b}$ \\
\hline & & 25 & $6.2 \mathrm{~b}$ & $266.3 \mathrm{~b}$ \\
\hline & & 100 & $9.3 \mathrm{~b}$ & $256.0 \mathrm{~b}$ \\
\hline & \multirow{3}{*}{ With } & 5 & $10.1 \mathrm{~b}$ & $244.8 \mathrm{~b}$ \\
\hline & & 25 & $7.2 \mathrm{~b}$ & $224.4 \mathrm{~b}$ \\
\hline & & 100 & $7.4 \mathrm{~b}$ & $244.3 \mathrm{~b}$ \\
\hline \multirow{6}{*}{ Solid } & \multirow{3}{*}{ Without } & 5 & $10.7 \mathrm{~b}$ & $242.9 \mathrm{~b}$ \\
\hline & & 25 & $16.8 \mathrm{a}$ & $213.9 \mathrm{~b}$ \\
\hline & & 100 & $13.7 \mathrm{a}$ & $267.3 \mathrm{~b}$ \\
\hline & \multirow{3}{*}{ With } & 5 & $15.1 \mathrm{a}$ & $190.1 \mathrm{~b}$ \\
\hline & & 25 & $20.0 \mathrm{a}$ & $254.3 \mathrm{~b}$ \\
\hline & & 100 & $15.8 \mathrm{a}$ & 386.7 a \\
\hline & Control & & $5.8 \mathrm{~b}$ & $194.6 \mathrm{~b}$ \\
\hline
\end{tabular}

${ }^{*}$ Means followed by the same lowercase letter in the same column do not differ statistically from each other at the level of $5 \%$ of error probability by the Scott-Knott test.

The use of adjuvant in both formulations (solid and liquid) increased the phytotoxicity. This is better illustrated in Figure 2, where the control test was compared with the solid formula containing $100 \%(v / v)$ of bioherbicide without adjuvant against $100 \%(v / v)$ of bioherbicide with adjuvant. The use of lettuce as a test plant may have influenced the phytotoxicity since lettuce leaves were smooth without hairiness. In this sense, the use of the adjuvant provided adhesiveness and better distribution of the biomolecules on the leaf surface, increasing the herbicidal action power on the plants $[2,30]$. Several authors have already performed studies showing the increase in the efficiency of the fermentative broths with the biomolecules using adjuvants $[13,14,31,32]$. Some authors have studied the influence of adjuvants on herbicides formulated with biomolecules of the fungus Diaporthe sp., where an increase in the herbicidal action with the use of adjuvants was achieved $[13,14]$.

Dry matters of treatments were lower than the control test. Statistical differences between treatments and control test $(p<0.05)$ were observed, but with little statistical variation among the treatments. The reduction of dry matter of treatments may be attributed to the oxidative stress that plants were submitted to after the application of bioherbicide. Under oxidative stress conditions, the plant spent energy to synthesize molecules to neutralize the reactive oxygen species (ROS) instead of synthesizing biomass. The antioxidant enzyme superoxide dismutase (SOD) is considered the first line of defense against damage caused by ROS, where it catalyzes the conversion of superoxide anion $\left(\mathrm{O}_{2}-^{*}\right)$ into $\mathrm{H}_{2} \mathrm{O}_{2}$ and $\mathrm{O}_{2}$ in the chloroplasts, mitochondria, cytoplasm, and peroxisomes [33].

The hypothesis presented above can be confirmed by comparing the activity of POD and SOD enzymes 2 DAA, since they are considered as antioxidant enzymes (Table 4). For POD enzyme activities, there was a statistical difference in the results of the solid formulation if compared to the control test, except for the solid formula containing $5 \%(v / v)$ of bioherbicide without the adjuvant $(p<0.05)$. The results of SOD enzyme activity showed that the solid formula containing $100 \%(v / v)$ bioherbicide with the adjuvant presented statistical difference if compared to the control test. In this treatment, an increase of $91.78 \%$ in the enzyme activity was achieved if compared to the control test. From the data in Tables 3 and 4, the effect of increasing the concentration of the fermented broth through the spray drying formulation was beneficial to increase the herbicidal action, together with the use of adjuvants that allowed the biomolecules to adhere to the leaves for infection. When comparing the treatments with the adjuvant, the increase in bioherbicide concentration from $5 \%(v / v)$ to $100 \%(v / v)$ resulted in the activation of the defense mechanisms of the lettuce test plant. 
The high activity of the SOD enzyme can explain the excellent control performed by the solid formula containing $100 \%(v / v)$ with the adjuvant, evidencing the herbicidal action of the biomolecules produced by the fungus Diaporthe sp. Several works have demonstrated the increase in ROS with an increase of certain stresses that wear out the plant, caused by biotic or abiotic factors. Ehsani-Moghaddam et al. [34] characterized the involvement of SOD during infection of the fungus Mycosphaerella fragariae in three strawberry cultivars and observed that the concentration level of this antioxidant enzyme on the second day after inoculation was high in all plants attacked by the phytopathogen when compared to the respective controls. The authors observed that the highest concentrations of SOD were in the resistant materials, and could be explained as a strategy of the plant to restrict the development of the fungus by the action of this antioxidant enzyme. De Freitas-Silva et al. [35] studied the effects of the herbicide glyphosate on the test plant Arabidopsis thaliana and observed that the treatment with the herbicide promoted an increase in the SOD activity. Some selective herbicides can cause the production of reactive oxygen species and oxidative stress. However, resistant plants balance the ROS and the antioxidant enzyme system, so that the crop does not die. In this sense, in another study, the herbicides oxyfluorfen and oxadiazon resulted in increased activity of the SOD enzyme. Although they are selective and registered in the control of weeds in rice culture, these herbicides can cause phytotoxicity, reduce the size, and alter plant metabolism, thus generating reactive oxygen species, which activate the enzymatic defense system [36].

In the solid formulation prepared by spray drying, the presence of the adjuvant and the high concentration of the fermented broth provided the highest activities of the antioxidant POD enzyme. As discussed earlier, when a plant is submitted to stress, the activation of the antioxidant enzymes is undertaken to balance the ROS. However, in some cases such as in the application of a herbicide, plants cannot reduce the ROS, and even increase the production of their antioxidant enzymes. Therefore, it causes the degradation of the membrane in most cases. Laxm et al. [37] studied the effect of herbicides on the weed Portulaca oleracea and concluded that 2,4-dichlorophenoxyacetic acid after $48 \mathrm{~h}$ of its application caused an increase in the activity of the antioxidant enzyme POD. The increase in the enzymatic activity was defined as the induction of the antioxidant system under the stress of the herbicide. Another study evaluated the enzymatic activity in conventional and transgenic soybean cultivars under the application of glyphosate herbicide. The conventional variety induced an increase in the activity of the POD enzyme, but the amount of POD in the transgenic variety was already high and did not need to be induced. Considering the results, the authors inferred that the activity of the POD enzyme could be used as a biochemical marker to distinguish between conventional and transgenic varieties [38]. Another study discussed the influence of reactive oxygen species (ROS) on the action of the herbicide glufosinate. The authors observed that ammonia accumulation is a physiological consequence of glutamine synthetase inhibition, which is not the principal cause of phytotoxicity. Therefore, ROS can be responsible for rapid glufosinate-induced cell death [39].

\section{Conclusions}

In this study, solid and liquid formulations containing biomolecules with herbicidal activity were tested. The solid formula presented the highest phytotoxicity on the control plant $(96.7 \%)$ and the phytotoxicity was directly related to the concentration of fermentative broth in the formula. The use of adjuvant improved the efficiency of bioherbicide. Dry matters of treatments were lower than the control and this was correlated with an increase in oxidative stress since the activity of the antioxidant enzymes such as SOD and POD increased in the treatment with a high level of phytotoxicity. Spray drying technology is a promising technology to concentrate bioherbicides without loss of bioactive compounds, once one of the major challenges in the production of bioherbicides, which is, the low concentration of the active ingredient in the fermented broth, is resolved. 
Author Contributions: Conceptualization, T.C.d.A., D.M.S., and M.A.M.; Data curation, M.V.T.; Formal analysis, O.E.; Investigation, T.C.d.A., S.S.S., T.B., S.S., D.M.S., S.H.B.D., G.L.Z., and R.C.K.; Methodology, T.C.d.A., T.B., S.S., O.E., and S.H.B.D.; Supervision, M.A.M.; Writing—original draft, G.L.Z., R.C.K., and M.A.M.; Writing一review \& editing, M.V.T., G.L.Z., R.C.K., and M.A.M. All authors have read and agreed to the published version of the manuscript.

Funding: This research was funded by Coordination of Superior Level Staff Improvement (CAPES), grant number 001 and National Council for Scientific and Technological Development (CNPq), grant numbers 428180/2018-03, 308936/2017-5 and 304882/2018-6.

Acknowledgments: The authors thank CAPES for the scholarships as well as CNPq for the financial support of this work.

Conflicts of Interest: The authors declare no conflicts of interest.

\section{References}

1. Duke, S.O.; Dayan, F.E.; Romagni, J.G.; Rimando, A.M. Natural products as sources of herbicides: Current status and future trends. Weed Res. 2000, 40, 99-111. [CrossRef]

2. Hoagland, R.E.; Boyette, C.D.; Weaver, M.A. Bioherbicides: Research and risks. Toxin Rev. 2007, 26, 313-342. [CrossRef]

3. Dayan, F.O.; Duke, S.O. Natural Compounds as Next Generation Herbicides. Plant Physiol. 2014, 166, 1090-1105. [CrossRef] [PubMed]

4. Heap, I. International Survey of Herbicide Resistant Weeds. Weed Sci. Soc. Am. 2019. Available online: http://www.weedscience.org (accessed on 25 November 2019).

5. Strange, R.N. Phytotoxins produced by plant pathogens. Nat. Prod. Rep. 2007, 24, 127-144. [CrossRef] [PubMed]

6. Cimmino, A.; Mais, M.; Evidente, M.; Superchi, S.; Evidente, A. Fungal phytotoxins with potential herbicidal activity: Chemical and biological characterization. RSC 2015, 16, 29-53. [CrossRef] [PubMed]

7. Udayanga, D.; Xingzhong, L.; Mckenzie, E.H.C.; Chukeatirote, E.; Bahkali, A.H.A.; Hyde, K.D. The genus Phomopsis: Biology, applications, species concepts and names of common pathogens. Fungal Divers. 2011, 50, 189-225. [CrossRef]

8. Dai, J.; Krohn, K.; Floerk, E.U.; Gehle, D.; Aust, H.J.; Draeger, S.; Schulz, B.; Rheinheimer, J. Novel highly substituted biraryl ethers, phomopsines D-G, isolated from endophytic fungus Phomopsis sp. from Adenocarpus foliolosus. Eur. J. Org. Chem. 2005, 23, 5100-5105. [CrossRef]

9. Lin, X.; Huang, Y.; Fang, M.; Wang, J.; Zheng, Z.; Su, W. Cytotoxic and antimicrobial metabolites from marine lignicolous fungi, Diaporthe sp. FEMS. Microbiol. Lett. 2005, 251, 53-58. [CrossRef]

10. Wu, S.H.; Chen, Y.W.; Shao, S.C.; Wang, L.D.; Li, Z.Y.; Yang, L.Y.; Li, S.L.; Huang, R. Ten-membered lactones from Phomopsis sp.; an endophytic fungus of Azadirachta Indica. J. Nat. Prod. 2008, 71, 731-734. [CrossRef]

11. Kumaran, R.S.; Hur, B. Screening of species of the endophytic fungus Phomopsis for the production of the anticancer drug taxol. Biotechnol. Appl. Bioc. 2009, 54, 21-30. [CrossRef]

12. Ash, G.J. The science art business of successful bioherbicides. Biol. Control 2010, 52, 230-240. [CrossRef]

13. Bastos, B.O.; Deobald, G.A.; Brun, T.; Dal Prá, V.; Junges, E.; Kuhn, R.C.; Pinto, A.K.; Mazutti, M.A. Solid-state fermentation for production of a bioherbicide from Diaporthe $\mathrm{sp}$. and its formulation to enhance the efficacy. 3 Biotech 2017, 7, 1-9. [CrossRef] [PubMed]

14. Pes, M.P.; Mazutti, M.A.; Almeida, T.C.; Curioletti, L.E.; Melo, A.A.; Guedes, J.V.C.; Kuhn, R.C. Bioherbicide based on Diaporthe sp. secondary metabolites in the control of three tough weeds. Afr. J. Agric. Res. 2016, 11, 4242-4249.

15. Souza, A.R.C.; Baldoni, D.B.; Lima, J.; Porto, V.; Marcuz, C.; Ferraz, R.C.; Kuhn, R.C.; Jacques, R.J.S.; Guedes, J.V.C.; Mazutti, M.A. Bioherbicide production by Diaporthe sp. isolated from the Brazilian Pampa biome. Biocatal. Agric. Biotechnol. 2015, 4, 575-578. [CrossRef]

16. Costa-Silva, T.A.; Said, S.; Souza, C.R.F.; Oliveira, W.P. Stabilization of Endophytic Fungus Cercospora kikuchii Lipase by Spray Drying in the Presence of Maltodextrin and Cyclodextrin. Drying Technol. 2010, 28, 1245-1254. [CrossRef] 
17. Liao, Y.H.; Brown, M.B.; Quader, A.; Martin, G.P. Investigation of the physical properties of spray-dried stabilized lysozyme particles. J. Pharm. Pharmacol. 2003, 55, 1213-1223. [CrossRef]

18. Marques, L.G.; Prado, M.M.; Freire, J.T. Rehydration characteristics of freeze dried tropical fruits. LWT 2009, 42, 1232-1237. [CrossRef]

19. Peighambardoust, S.H.; Golshan, T.A.; Hesari, J. Application of spray drying for preservation of latic acid starter cultures: A review. Trends Food Sci. Technol. 2011, 22, 215-224. [CrossRef]

20. Kamoun, A.S.; Haddar, A.; Ali, N.E.; Frikha, B.G.; Kanoun, S.; Nasri, M. Stability of thermostable alkaline protease from Bacillus licheniformis RP1 in commercial solid laundry detergent formulations. Microbiol. Res. 2008, 163, 299-306. [CrossRef] [PubMed]

21. Jesus, S.S.; Maciel Filho, R. Drying of $\alpha$-amylase by spray drying and freeze drying-A comparative study. Braz. J. Chem. Eng. 2013, 31, 625-631. [CrossRef]

22. Frans, R.; Crowley, H. Experimental Design and Techniques for Measuring and Analyzing Plant Responses to Weed Control Practices. In Southern Weed Science Society. Research Methods in Weed Science, 3rd ed.; Clemson: South Carolina, SC, USA, 1986; pp. 29-45.

23. Giannopolitis, C.N.; Ries, S.K. Superoxide dismutase. I. Occurrence in higher plants. Plant Physiol. 1977, 59, 309-314. [CrossRef] [PubMed]

24. Zeraik, A.E.; Souza, F.S.; Fatibello-Filho, O. Desenvolvimento de um spot test para o monitoramento da atividade da peroxidase em um procedimento de purificação. Quím. Nova 2008, 31, 731-734. [CrossRef]

25. Ferreira, D.F. Sisvar: A Computer Statistical Analysis System. Ciência e Agrotecnologia (UFLA) 2011, 35, 1039-1042. [CrossRef]

26. Varejão, E.V.V.; Demuner, A.J.; Barbosa, L.C.A.; Barreto, R.W.; Veira, B.S. Toxicidade de filtrados de cultura de Alternaria euphorbiicola em folhas de Euphorbia heterophylla. Planta Daninha (Impresso) 2013, 31, 1-9. [CrossRef]

27. Todero, I.; Confortin, T.C.; Soares, J.F.; Brun, T.; Luft, L.; Rabuske, J.E.; Kuhn, R.C.; Tres, M.V.; Zabot, G.L.; Mazutti, M.A. Concentration of metabolites from Phoma sp. using microfiltration membrane for increasing bioherbicidal activity. Environ. Technol. 2018, 40, 2364-2372. [CrossRef]

28. Meng, X.; Yu, J.; Yu, M.; Yin, X.; Liu, Y. Dry flowable formulations of antagonistic Bacillus subtilis strain T429 by spray drying to control rice blast disease. Biol. Cont. 2015, 55, 46-51. [CrossRef]

29. Oancea, F.; Raut, I.; Şesan, T.E.; Cornea, P.C. Dry Flowable Formulation of Biostimulants Trichoderma Strains. Agric. Agric. Sci. Procedia 2016, 10, 494-502. [CrossRef]

30. Piyaboon, O.; Pawongrat, R.; Unartngam, J.; Chinawong, S. Pathogenicity, host range and activities of a secondary metabolite and enzyme from Myrothecium roridum on water hyacinth from Thailand. Weed Biol. Manag. 2016, 16, 132-144. [CrossRef]

31. Brun, T.; Rabuske, J.E.; Todero, I.; Almeida, T.C.; Junior, J.J.D.; Ariotti, G.; Confortin, T.; Arnemann, J.A.; Kuhn, R.C.; Guedes, J.V.C.; et al. Production of bioherbicide by Phoma sp. in a stirred-tank bioreactor. 3 Biotech 2016, 6, 230-238. [CrossRef]

32. Todero, I.; Confortin, T.C.; Luft, L.; Brun, T.; Ugalde, G.A.; Almeida, T.C.; Arneman, J.A.; Zabot, G.L.; Mazutti, M.A. Formulation of a bioherbicide with metabolites from Phoma sp. Sci. Hortic. 2018, 241, $285-292$. [CrossRef]

33. Wang, W.; Lu, J.; Ren, T.; Li, X.K.; Su, W.; Lu, M. Evaluating regional mean optimal nitrogen rates in combination with indigenous nitrogen supply for rice production. Field Crops Res. 2012, 137, 37-48. [CrossRef]

34. Ehsani-Moghaddam, B.; Charles, M.T.; Carisse, O.; Khanizadeh, S. The effect of leaf spot disease on specific antioxidant activity of strawberry. Acta Horti. 2007, 744, 329-334. [CrossRef]

35. Freitas-Silva, L.; Rodriguez-Ruiz, M.; Houmani, H.; Silva, L.C.; Palma, J.M. Glyphosate-induced oxidative stress in Arabidopsis thaliana affecting peroxisomal metabolism and triggers activity in the oxidative phase of the pentose phosphate pathway OxPPP involved in NADPH generation. J. Plant. Physiol. 2017, 218, 196-205. [CrossRef] [PubMed]

36. Langaro, A.C.; Agostinetto, R.Q.; Garcia, J.R.; Perboni, L.T. Oxidative stress caused by the use of preemergent herbicides in rice crops. Rev. Ciên. Agron. 2017, 48, 358-364. [CrossRef]

37. Laxmi, S.; Chambhare, M.R.; Kadlag, S.; Ahire, M.L.; Nikam, T.D. Herbicide effects on pigments and antioxidant enzymes of Portulaca oleracea. J. Pharmacogn. Phytochem. 2018, 7, 2024-2031. 
38. Moldes, C.A.; Medici, L.O.; Abrahão, O.S.; Tsai, S.M.; Azevedo, R.A. Biochemical responses of glyphosate resistant and susceptible soybean plants exposed to glyphosate. Acta Physiol. Plant. 2008, 30, 469-479. [CrossRef]

39. Takano, H.K.; Beffa, R.; Preston, C.; Westra, P.; Dayan, F.E. Reactive oxygen species trigger the fast action of glufosinate. Planta 2019, 249, 1837-1849. [CrossRef] 